\title{
Role of Nutritional Status in Predicting the Length of Stay in Cancer: A Systematic Review of the Epidemiological Literature
}

\author{
Digant Gupta Pankaj G. Vashi Carolyn A. Lammersfeld Donald P. Braun
}

Cancer Treatment Centers of America ${ }^{\circledR}$ at Midwestern Regional Medical Center, Zion, III., USA

\section{Key Words}

Length of hospital stay $\cdot$ Malnutrition $\cdot$ Nutritional

assessment, screening, status · Oncology

\begin{abstract}
Background: Length of stay (LOS) has been used as a surrogate marker for patients' well-being during hospital treatment. We systematically reviewed all pertinent literature on the role of nutritional status in predicting LOS in cancer. Methods: A systematic search of human studies published in English was conducted using the MEDLINE data base (all articles published as of December 2010). We searched using the terms 'nutritional status' and 'nutritional assessment' and 'nutritional screening' and 'malnutrition' in combination with the following terms: length of stay, length of hospital stay, duration of stay, and duration of hospitalization together with 'cancer' or 'oncology'. Results: The MEDLINE search identified a total of 149 articles, of which only 21 met the selection criteria. Of the 21 studies, 10 studies investigated gastrointestinal cancer patients, 4 gynecological cancer, and 7 heterogeneous cancer. Eight studies used subjective global assessment (SGA) or patient-generated SGA (PG-SGA), 9 used serum albumin and/or BMI, and 4 used other methods of nutritional assessment. Conclusions: Validated nutritional tools such as SGA/PG-SGA are better predictors of LOS in gastrointestinal cancers requiring surgery than in nonsurgical gastrointestinal cancer patients. Correcting malnutrition may decrease the LOS and perhaps even lower the rate of hospital readmissions in this population.
\end{abstract}

Copyright $\odot 2011$ S. Karger AG, Basel

\section{KARGER}

Fax +41613061234

E-Mail karger@karger.ch

www.karger.com

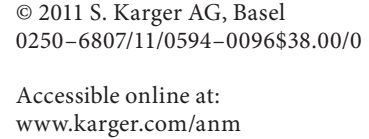

\section{Introduction}

Cancer patients are particularly susceptible to nutritional depletion due to the combined effects of the malignant disease and its treatment $[1,2]$. Treatment modalities involving chemotherapy, radiotherapy, and surgery are all known to negatively affect nutritional status. Although the prevalence and magnitude of a diminished nutritional status varies with individual treatment regimens, it is widely accepted that the principal causes related to therapy are the result of commonly experienced side effects such as nausea, vomiting, anorexia, lethargy, diarrhea, esophagitis, and dysphagia $[3,4]$.

The incidence of malnutrition among patients with cancer has been estimated at between 40 and $80 \%$ [5-8]. Nearly $20 \%$ of cancer patients are reported to die of malnutrition or its associated complications rather than the malignant disease itself [9]. The prevalence of malnutrition depends on the tumor type, tumor location, stage of the disease, and treatment received and on the type of nutritional assessment method used [5]. These considerations provide a strong rationale for regular nutritional assessment and management for all cancer patients throughout the course of their disease.

An extensive and diverse set of methods are available for assessing nutritional status in cancer patients. Each has its strengths and weaknesses. Among the most commonly employed are: (i) anthropometric measurements, e.g. weight change, arm muscle circumference, and triceps skinfold thickness; (ii) quantitative biochemical assays, e.g.

\footnotetext{
Digant Gupta, MD, MPH

Cancer Treatment Centers of America

2520 Elisha Avenue

Zion, IL 60099 (USA)

Tel. +1 847872 6241,E-Mail gupta_digant@yahoo.com
} 
serum albumin, transferrin, and nitrogen balance studies; (iii) subjective global assessment (SGA) based on medical history and physical examination; patient-generated SGA (PG-SGA) adapted from the SGA specifically for cancer patients; (iv) the malnutrition screening tool (MST), considered the quickest and most simple tool for nutritional screening by the American Society for Parenteral and Enteral Nutrition (ASPEN); (v) Nutritional Risk Screening 2002 (NRS-2002), designed to detect malnutrition and the risk of developing malnutrition in the hospital setting as recommended by the European Society for Clinical Nutrition and Metabolism (ESPEN) [10], and (vi) the Malnutrition Universal Screening Tool (MUST), developed by the British Association for Parenteral and Enteral Nutrition, devised for application in all adult patients across all health care settings [1]. Many other nutritional parameters, including the Prognostic Nutritional Index, the Nutritional Risk Index, the Nutritional Screening Tool, the Maastricht Index, the Instant Nutrition Assessment, and the Mini Nutritional Assessment, have also been used to attempt to risk stratify patients $[3,11,12]$. The utility of these nutritional screening tools has been evaluated by their ability to predict relevant clinical outcomes, such as complications, treatment response, survival, hospital length of stay (LOS), and higher costs of health care $[4,9,13]$.

LOS has been used as a surrogate marker of patients' well-being during hospital treatment [14] and is considered to reflect integration of the severity of illness and the patient's health status affected by genetics, the extent or severity of the trauma or disease, the overall medical or surgical treatment, the quality of care, and the availability of intermediary and long-term care facilities [3]. Reducing the LOS, therefore, has the potential to decrease health care costs, the risk of infections, and other hospital-acquired diseases and to improve patients' quality of life [14]. Malnourished patients often experience a significantly prolonged treatment duration in association with increased morbidities, thereby increasing the LOS [15]. Although the literature provides evidence of an association between nutritional status and LOS in cancer, there are considerable differences among individual studies with respect to the patient population, study design, sample size, and type of nutritional assessment.

The objective of this manuscript was to systematically review all of the pertinent literature on the relationship between nutritional status and LOS in cancer with the goal of consolidating and presenting the evidence while attempting to elucidate the most significant clinical implications and directions for future research in this area.

Nutrition and LOS in Cancer

\section{Methods}

\section{Data Sources}

The MEDLINE data base was used to identify all articles investigating the relationship between nutritional status and LOS in cancer patients (all articles published as of December 2010). We also searched the bibliographies of selected papers to identify relevant articles missed during the primary MEDLINE search.

\section{Study Eligibility Criteria}

To be included in the review, an article must have: been published in English, reported data collected in humans with cancer, had nutritional status/assessment/screening as one of the predictor variables, had LOS as one of the outcome measures (primary or secondary), and utilized any of the following study designs (case-control, cohort, cross-sectional, prospective, retrospective, case series, longitudinal, clinical trial, meta-analysis). There were no restrictions in terms of age, ethnicity, or type or stage of cancer.

Search

We searched using the terms 'nutritional status' and 'nutritional assessment' and 'nutritional screening' and 'malnutrition' in combination with the following terms: length of stay, length of hospital stay, duration of stay and duration of hospitalization together with 'cancer' or 'oncology'.

\section{Study Selection}

Screening and eligibility assessment of the articles to be included were performed independently by 2 reviewers. Disagreements between reviewers were resolved by consensus.

Data Collection Process

One review author extracted the required data elements from included articles and the second author verified the extracted data. Disagreements were resolved by discussion between the two review authors. Tables $1-3$ reflect the template for data collection.

\section{Data Items}

The following information was extracted for each included article: first author, year of publication, study place, data collection period, study design, sample size, nutritional assessment method, nutritional groups being compared, LOS comparison across the nutritional groups, conclusion, and variables adjusted for.

\section{Synthesis of Results}

The methods for assessing nutritional status were very varied across the selected articles. The only method that has been validated is the SGA/PG-SGA, so we wanted to evaluate results comparing a validated method versus other methods like BMI and serum albumin, which are not validated. As a result, all articles reviewed are summarized in separate tables based on the type of nutritional assessment method used to enable meaningful conclusions to be drawn separately for different nutritional assessment methods as well as to categorize studies into comparable groups in terms of the number of articles in each table. Within each table, studies are arranged chronologically by the year of publication starting with the most recently published study. 


\section{Results}

\section{Study Selection}

The MEDLINE search identified a total of 149 articles based on different combinations of the search terms described above. The titles and abstracts of these 149 articles were reviewed to identify the relevant articles based on the selection criteria described above. Of these 149 articles, 124 were excluded because after reviewing the abstracts it appeared that these papers clearly did not meet the selection criteria. The full texts of the remaining 25 articles were obtained and reviewed. Four more articles failed to meet the selection criteria and were excluded. Finally, 21 articles were selected for the purpose of final inclusion and review in this manuscript. A flowchart describing the results of our literature search is provided in figure 1.

\section{Characteristics of Included Studies}

A total of 21 articles published in English were included in this review. For each study included, the data were extracted for the following characteristics: first author, year of publication, study place, data collection period, study design, sample size, nutritional assessment method, nutritional groups being compared, LOS comparison across the nutritional groups, conclusion, and variables adjusted for.

\section{Synthesis of Results}

Nutritional Status and LOS - SGA and PG-SGA

Table 1 describes studies exploring the relationship between nutritional status and LOS using SGA or PG-SGA as the primary nutritional assessment method. Of the 8 studies described herein, 6 were prospective $[9,14,16-19]$ and 2 were retrospective $[5,20]$. The sample size ranged from a minimum of 66 [20] to a maximum of 751 [9]. Populations under study included patients with gastrointestinal cancer, gynecologic cancer, head and neck cancer, multiple myeloma, and lymphoma. The studies divided their population into 3 SGA categories designated A, B, and $C$ representing well-nourished, moderately malnourished, and severely malnourished individuals, respectively. PG-SGA was used as a continuous variable in one study [20]. Notably, SGA was found to be a significant predictor of LOS in all 8 studies such that the mean LOS was significantly higher in the malnourished groups versus the well-nourished groups. Wu et al. [19] found a significant increase in LOS in severely malnourished (SGA C) patients compared to well-nourished (SGA A) or moderately malnourished (SGA B) patients. Another study by $\mathrm{Wu}$ et al. [9] suggested that SGA may be a better tool for pre-

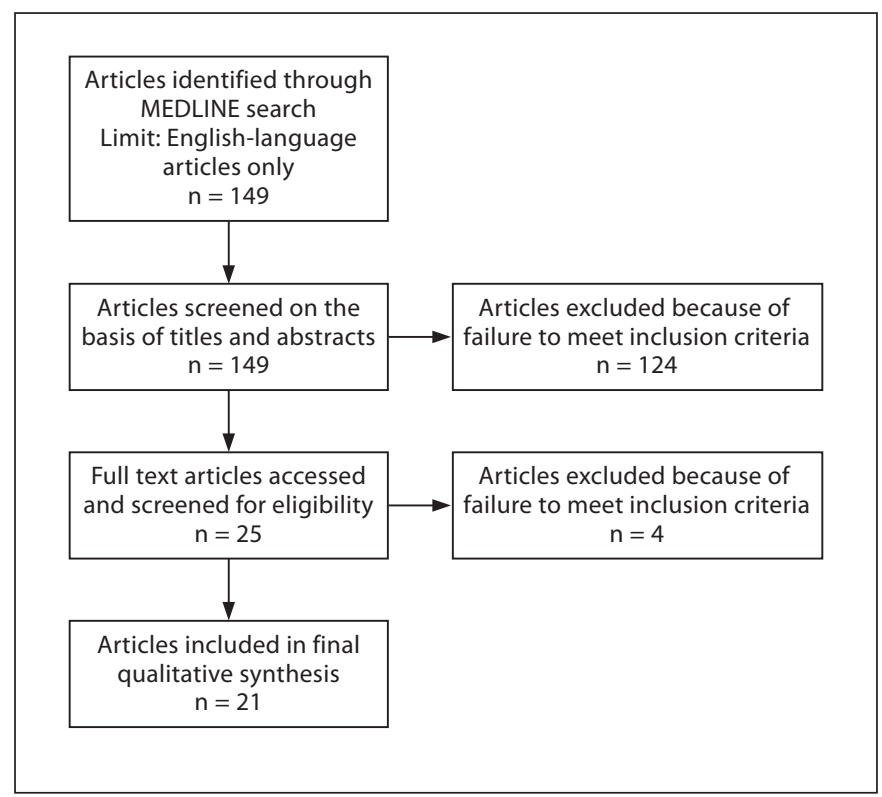

Fig. 1. Flowchart depicting the MEDLINE search results.

dicting LOS in surgical gastrointestinal cancer patients compared to all gastrointestinal cancer patients.

Nutritional Status and LOS - BMI or Serum

Albumin or Both

Table 2 describes studies exploring the relationship between nutritional status and LOS using either BMI, serum albumin, or both as the nutritional assessment method(s). Of the 9 studies described herein, 6 were retrospective $[13,21-25]$ while 3 were prospective $[12,26$, 27]. The sample size ranged from a minimum of 84 [13] to a maximum of 2,258 [27]. Study populations included patients with gastrointestinal cancer, gynecologic cancer, leukemia, or lymphoma and patients undergoing various cancer surgeries. Three studies used BMI only [12, 26, 27], 1 used serum albumin only [13], and 5 used a combination of both [21-25]. In the 3 studies using BMI as the nutritional assessment method, no relationship between BMI and LOS was demonstrated. The study using serum albumin found a statistically significant longer LOS in the hypoalbuminemic group versus the nonhypoalbuminemic group. In the remaining 5 studies using a combination of BMI and serum albumin, BMI was not significantly associated with LOS, while albumin levels were in 4 of the 5 studies $[21-23,25]$. 
Nutritional Status and LOS - Other Measures

Table 3 includes studies examining the relationship between nutritional status and LOS using other nutritional assessment measures such as NRS-2002, MUST, and MST $[1,10]$. One study used the recommendations of the French health authority to define malnutrition using age, BMI, and weight loss [28], while another one used the Prognostic Nutritional Index based on serum albumin, transferrin, triceps skinfolds, and skin sensitivity tests [29]. Of the 4 studies described herein [1, 10, 28, 29], all were prospective. The sample size ranged from a minimum of 67 [29] to a maximum of 1,545 [28]. The populations studied involved patients with the following cancers: breast, head and neck region, colorectal region, colon, lung, digestive system, genitourinary, endocrine glands, soft tissues, respiratory system, thoracic region, bones and joints, eye and lachrymal region, hematologi$\mathrm{cal}$, and hematopoietic system. All 4 studies found a higher LOS associated with malnourished status.

\section{Discussion}

The present study aimed to review the literature on the relationship between nutritional status and LOS in cancer. A total of 21 articles were selected for the purpose of final inclusion and review in this manuscript. Of the 21 studies, 10 studies investigated gastrointestinal cancer patients, 4 investigated gynecological cancer patients, and 7 investigated heterogeneous or multiple cancer patients. Among the 10 studies looking at the association between nutritional status and LOS in gastrointestinal cancer patients, only 4 studies showed that a better nutritional status was associated with a shorter LOS. The remaining 6 studies showed that nutritional status did not have any significant impact on LOS. Among the 4 studies exploring the relationship between nutritional status and LOS in gynecological cancers, 2 studies showed that a better nutritional status was associated with a shorter LOS. The tools used in these studies were PG-SGA [14] and the Prognostic Nutrition Index [29], respectively. In the remaining 2 studies, BMI was not found to be associated with LOS while serum albumin levels were. Among the 7 studies exploring the relationship between nutritional status and LOS in heterogeneous samples of cancer patients, 6 studies showed that malnourished status was significantly associated with a longer LOS. One of these studies mentioned that, though SGA was predictive of LOS, the study was underpowered to undertake multivariate analysis to overcome the is- sues related to bias and confounding [16]. One study, however, showed no association between nutritional status and LOS [21].

SGA is the only MST recommended by the ASPEN board of directors [16]. SGA is a simple, easy-to-apply and cost-effective method that has been validated for diverse groups of patients. SGA is one of the better available assessment methods, not only because it is patient centered and incorporates the clinical history and physical examination but also because it does not require laboratory testing or medical imaging exams $[18,19]$. Reliable SGA grading, however, depends on the collection of a correct history and physical observation and requires a skilled dietician to carry out the assessment [18]. Nutrition assessment tools such as the scored PG-SGA enable quick assessment of the nutritional status, identification of nutrition impact symptoms, and implementation of appropriate nutrition support. An advantage of the PGSGA as a nutrition assessment tool is that the score can be used as an outcome measure in nutrition intervention studies as it may be more sensitive to changes in nutritional status than the global SGA rating [20]. Also, by performing serial measurements, the change in the PGSGA score may be used to demonstrate subtle changes in nutritional status. The high sensitivity and specificity of the PG-SGA score indicates that it strongly predicts nutritional status as defined by SGA. Unlike SGA, which places patients into categories, the continuous scoring system of the PG-SGA allows prioritization of patients requiring more urgent treatment and thus may facilitate a more effective use of resources [5]. In this review, 8 studies used SGA/PG-SGA as a validated nutritional assessment tool and in all 8 studies SGA/PG-SGA was found to be a significant predictor of LOS such that the mean LOS was significantly higher in the malnourished groups versus the well-nourished groups.

While serum albumin was found to be a predictor of LOS in 5 out of the 6 studies reviewed, and has long been associated with poor outcomes, this is more likely due to inflammatory metabolism and a decreased synthesis of negative acute-phase proteins than to nutritional status $[30,31]$. Although serum albumin is often used to assess nutritional status because it is easy and inexpensive, it is really more of an indicator of the severity of the illness rather than changes in nutritional status [32]. It is not recommended as a sole indicator of nutritional status because of the effect of the inflammatory process on its synthesis as well as the fact that it can be affected by many acute interventions and hydration status. Another example of the limitations of serum albumin as an indicator of 
Table 1. Relationship between nutritional status (assessed using SGA and PG-SGA) and LOS

\begin{tabular}{|c|c|c|c|c|c|}
\hline $\begin{array}{l}\text { First author, } \\
\text { year } \\
\text { (study place) }\end{array}$ & $\begin{array}{l}\text { Data } \\
\text { collection } \\
\text { period }\end{array}$ & $\begin{array}{l}\text { Study } \\
\text { design }\end{array}$ & Sample size & $\begin{array}{l}\text { Nutritional } \\
\text { assessment } \\
\text { method }\end{array}$ & Groups being compared \\
\hline $\begin{array}{l}\text { Laky, } 2010 \\
\text { (Australia) } \\
{[14]}\end{array}$ & $\begin{array}{l}\text { March } 2004 \text { to } \\
\text { December } 2006\end{array}$ & Prospective & $\begin{array}{l}157 \text { patients with presumed } \\
\text { or proven primary } \\
\text { gynecological cancer }\end{array}$ & PG-SGA & $\begin{array}{l}\text { PG-SGA A: well nourished }(\mathrm{n}=118) \text { (reference group) } \\
\text { PG-SGA B and C: moderately malnourished or suspected } \\
\text { of being malnourished and severely malnourished }(n=39)\end{array}$ \\
\hline
\end{tabular}

\begin{tabular}{|c|c|c|c|c|c|}
\hline $\begin{array}{l}\text { Wu, } 2010 \\
\text { (China) [19] }\end{array}$ & $\begin{array}{l}\text { August } 2004 \text { to } \\
\text { August } 2006\end{array}$ & Prospective & $\begin{array}{l}505 \text { gastrointestinal cancers: } \\
\text { gastric }(n=258), \text { colorectal } \\
(n=247)\end{array}$ & SGA & $\begin{array}{l}\text { SGA-A: well nourished }(n=275) \\
\text { SGA-B: mildly to moderately malnourished }(n=214) \\
\text { SGA-C: severely malnourished }(n=14)\end{array}$ \\
\hline $\begin{array}{l}\text { Wu, } 2009 \\
\text { (China) [9] }\end{array}$ & $\begin{array}{l}\text { August } 2004 \text { to } \\
\text { August } 2006\end{array}$ & Prospective & $\begin{array}{l}751 \text { adult patients diagnosed } \\
\text { with gastrointestinal cancer } \\
\text { (including stomach, colon, } \\
\text { or rectal cancer) }\end{array}$ & SGA & $\begin{array}{l}\text { SGA-A: well nourished }(\mathrm{n}=389) \\
\text { SGA-B: mildly to moderately malnourished }(\mathrm{n}=332) \\
\text { SGA-C: severely malnourished }(\mathrm{n}=30)\end{array}$ \\
\hline
\end{tabular}

\begin{tabular}{|c|c|c|c|c|c|}
\hline $\begin{array}{l}\text { Wakahara, } \\
2007 \\
\text { (Japan) [18] }\end{array}$ & $\begin{array}{l}\text { July } 2004 \text { to } \\
\text { April } 2005\end{array}$ & Prospective & $\begin{array}{l}262 \text { patients with digestive } \\
\text { diseases, } 110 \text { patients with } \\
\text { cancer }\end{array}$ & SGA & $\begin{array}{l}\text { SGA A: normal nutrition }(\mathrm{n}=138) \\
\text { SGA B: moderate malnutrition }(\mathrm{n}=81) \\
\text { SGA C: severe malnutrition }(\mathrm{n}=43)\end{array}$ \\
\hline $\begin{array}{l}\text { Horsley, } 2005 \\
\text { (Australia) } \\
{[20]}\end{array}$ & NA & $\begin{array}{l}\text { Retrospec- } \\
\text { tive consec- } \\
\text { utive case } \\
\text { series }\end{array}$ & $\begin{array}{l}66 \text { cancers patients. } \\
\text { Type: multiple myeloma } \\
(\mathrm{n}=27) \text {, non-Hodgkin's } \\
\text { lymphoma }(\mathrm{n}=13) \text {, B-cell } \\
\text { lymphoma }(\mathrm{n}=5) \text {, chronic } \\
\text { lymphocytic leukemia }(\mathrm{n}= \\
4) \text {, acute myeloid lymphoma } \\
(\mathrm{n}=2) \text {, Ewing's sarcoma } \\
(\mathrm{n}=2) \text {, others }(\mathrm{n}=13)\end{array}$ & PG-SGA & $\begin{array}{l}\text { According to the SGA, patients could be categorized as } \\
\text { follows: } \\
\qquad \text { SGA A: well nourished }(\mathrm{n}=48) \\
\text { SGA B: moderately malnourished }(\mathrm{n}=15) \\
\text { SGA C: severely malnourished }(\mathrm{n}=3) \\
\text { The PG-SGA score was used as a continuous variable }\end{array}$ \\
\hline $\begin{array}{l}\text { Shirodkar, } \\
2005 \\
\text { (India) [16] }\end{array}$ & $\begin{array}{l}\text { February } 1999 \\
\text { and } \\
\text { November } 1999\end{array}$ & $\begin{array}{l}\text { Prospective } \\
\text { observational } \\
\text { study, } \\
\text { consecutive } \\
\text { patients }\end{array}$ & $\begin{array}{l}266 \text { cancer patients. } \\
\text { Type: head and neck region } \\
(\mathrm{n}=112) \text {, gastrointestinal } \\
\text { tract }(\mathrm{n}=53) \text {, breast } \\
(\mathrm{n}=30) \text {, thorax }(\mathrm{n}=28), \\
\text { genitourinary tract }(\mathrm{n}=27) \text {, } \\
\text { bone and soft tissue }(\mathrm{n}=16)\end{array}$ & SGA and BMI & $\begin{array}{l}\text { Preoperative malnutrition groups based on BMI levels: } \\
\text { Nil-mild: }<18.5(\mathrm{n}=110) \\
\text { Moderate: } 18.5-20.0(\mathrm{n}=53) \\
\text { Severe: }>20.0(\mathrm{n}=103) \\
\text { Based on SGA scores: } \\
\text { SGA A: none or minimal malnutrition }(\mathrm{n}=152) \\
\text { SGA B: moderate malnutrition }(\mathrm{n}=98) \\
\text { SGA C: severe malnutrition }(\mathrm{n}=16)\end{array}$ \\
\hline $\begin{array}{l}\text { Bauer, } 2002 \\
\text { (Australia) [5] }\end{array}$ & 3-month period & $\begin{array}{l}\text { Retrospec- } \\
\text { tive conve- } \\
\text { nience sam- } \\
\text { ple }\end{array}$ & $\begin{array}{l}71 \text { cancer patients. } \\
\text { Type: lymphoma ( } 49 \%) \text {, } \\
\text { breast }(13 \%) \text {, prostate, } \\
\text { esophagus, lung, sarcoma } \\
\text { and myeloma ( } 4 \%)\end{array}$ & SGA & $\begin{array}{l}\text { SGA A: well nourished }(n=17) \\
\text { SGA B: moderately or suspected of being malnourished } \\
(n=42) \\
\text { SGA C: severely malnourished }(n=12)\end{array}$ \\
\hline $\begin{array}{l}\text { Ulander, } \\
1998 \\
\text { (Sweden) [17] }\end{array}$ & $\begin{array}{l}\text { November } 1992 \\
\text { to } \\
\text { June } 1994\end{array}$ & $\begin{array}{l}\text { Prospective } \\
\text { consecutive } \\
\text { case series }\end{array}$ & 75 colorectal cancer patients & $\begin{array}{l}\text { SGA } \\
\text { Preoperative } \\
\text { weight loss } \\
\text { Weight loss } \\
\text { during } \\
\text { hospitalization }\end{array}$ & $\begin{array}{l}\text { SGA A: well nourished }(\mathrm{n}=71) \\
\text { SGA B or C: malnourished }(\mathrm{n}=4)\end{array}$ \\
\hline
\end{tabular}




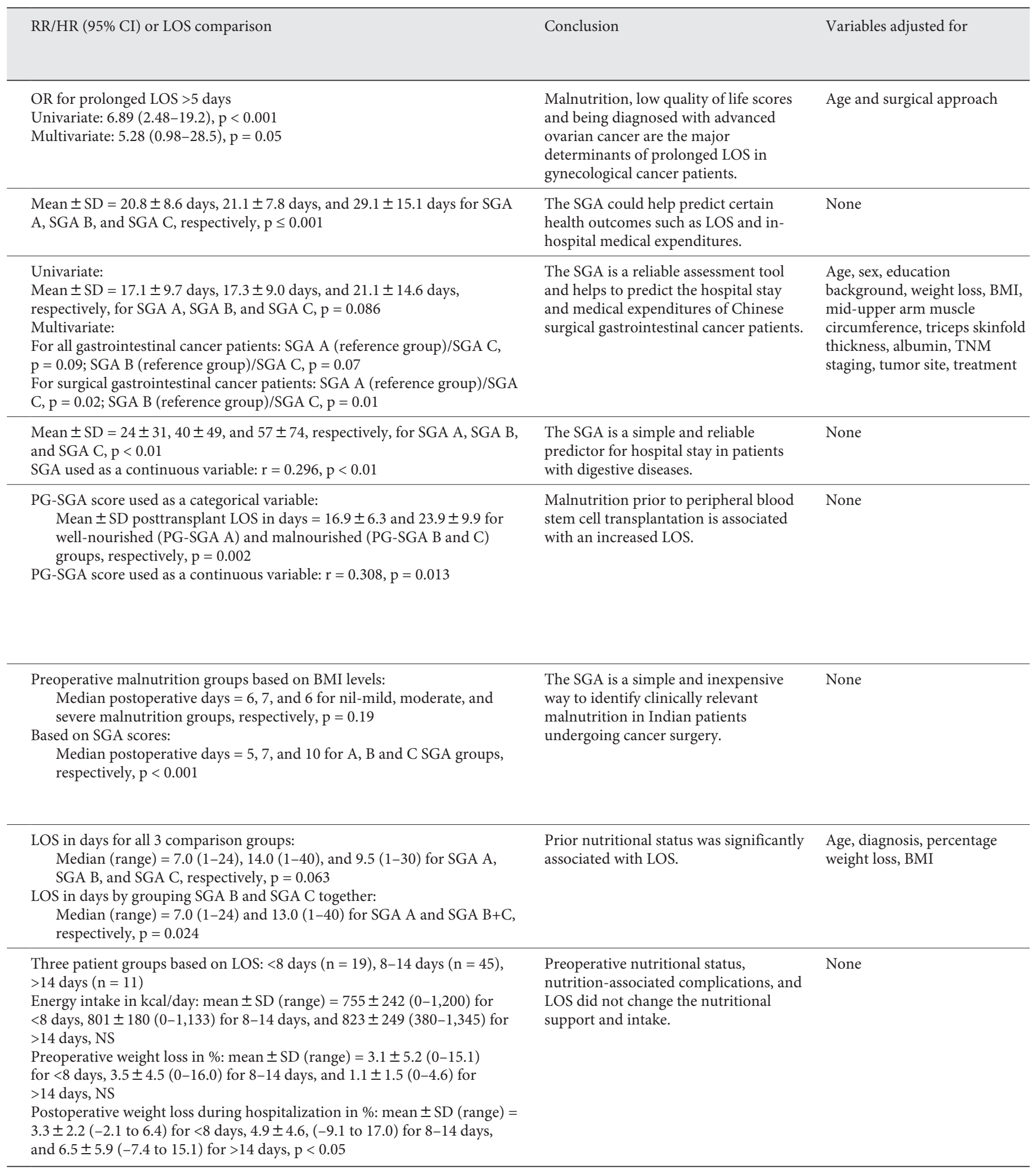


Table 2. Relationship between nutritional status (assessed using BMI or serum albumin or both) and LOS

\begin{tabular}{|c|c|c|c|c|c|}
\hline $\begin{array}{l}\text { First author, } \\
\text { year (study } \\
\text { place) }\end{array}$ & $\begin{array}{l}\text { Data } \\
\text { collection } \\
\text { period }\end{array}$ & $\begin{array}{l}\text { Study } \\
\text { design }\end{array}$ & Sample size & $\begin{array}{l}\text { Nutritional } \\
\text { assessment } \\
\text { method }\end{array}$ & Groups being compared \\
\hline $\begin{array}{l}\text { Beghetto, } 2009 \\
\text { (Brazil) [21] }\end{array}$ & $\begin{array}{l}2002 \text { and } \\
2004\end{array}$ & $\begin{array}{l}\text { Retro- } \\
\text { spective }\end{array}$ & $\begin{array}{l}\text { Total patients: } \mathrm{n}=434 \\
\text { Only cancer patients: } \\
\mathrm{n}=169\end{array}$ & $\begin{array}{l}\text { BMI } \\
\text { Albumin } \\
\text { SGA } \\
\text { Weight loss } \\
\text { Serum } \\
\text { lymphocyte count }\end{array}$ & $\begin{array}{l}\text { BMI } \geq 18.5(\mathrm{n}=46)(\text { reference group) and }<18.5(\mathrm{n}=386) \\
\text { Albumin }>3.5 \mathrm{~g} / \mathrm{dl} \text { (reference group) and }<3.5 \mathrm{~g} / \mathrm{dl}(\mathrm{n}=99) \\
\text { SGA A (well nourished) }(\mathrm{n}=212)(\text { reference group), SGA B } \\
\text { (moderately malnourished or suspicious for malnutrition) } \\
(\mathrm{n}=83) \text {, and SGA C (severely malnourished) }(\mathrm{n}=139) \\
\text { Weight loss }<5 \% \text { (reference group) and }>5 \%(\mathrm{n}=216) \\
\text { Serum lymphocyte count }>1,500 \mathrm{U} / \mu \mathrm{l} \text { (reference group) and } \\
\leq 1,500 \mathrm{U} / \mu \mathrm{l}(\mathrm{n}=249)\end{array}$ \\
\hline $\begin{array}{l}\text { Hendry, } \\
2009 \text { (Northern } \\
\text { Europe) [26] }\end{array}$ & $\begin{array}{l}\text { March } 2002 \\
\text { to December } \\
2005\end{array}$ & $\begin{array}{l}\text { Pro- } \\
\text { spective }\end{array}$ & $\begin{array}{l}1,035 \text { open colorectal } \\
\text { surgery patients }\end{array}$ & BMI & $\mathrm{BMI}<20$ and $\geq 20$ \\
\hline $\begin{array}{l}\text { Leung, } \\
2009 \text { (USA) } \\
{[24]}\end{array}$ & 2002-2007 & $\begin{array}{l}\text { Retro- } \\
\text { spective }\end{array}$ & $\begin{array}{l}183 \text { patients undergoing } \\
\text { colorectal resection for } \\
\text { neoplasms }\end{array}$ & $\begin{array}{l}\text { BMI and decrease } \\
\text { in serum albumin }\end{array}$ & $\begin{array}{l}\mathrm{BMI}<30 \text { and } \geq 30 \\
\text { Albumin change }<70 \%(\mathrm{n}=87) \text { and } \geq 70 \%(\mathrm{n}=96)\end{array}$ \\
\hline $\begin{array}{l}\text { Skipworth, } \\
2009 \\
(\mathrm{UK})[12]\end{array}$ & $\begin{array}{l}\text { January } 2001 \\
\text { to } \\
\text { March } 2004\end{array}$ & $\begin{array}{l}\text { Pro- } \\
\text { spective }\end{array}$ & $\begin{array}{l}93 \text { patients with esophago- } \\
\text { gastric carcinoma. } \\
\text { Type: esophagic }(\mathrm{n}=40) \text {, } \\
\text { gastric }(\mathrm{n}=53)\end{array}$ & $\begin{array}{l}\text { BMI and weight } \\
\text { loss }\end{array}$ & $\begin{array}{l}\text { Four groups: } \\
\text { No weight loss and BMI }>25(\mathrm{n}=34) \\
\text { No weight loss and BMI }<25(\mathrm{n}=14) \\
\text { Weight loss and BMI }>25(\mathrm{n}=20) \\
\text { Weight loss and BMI }<25(\mathrm{n}=25)\end{array}$ \\
\hline $\begin{array}{l}\text { Mullen, } 2008 \\
\text { (USA) [27] }\end{array}$ & 2001-2004 & $\begin{array}{l}\text { Pro- } \\
\text { spective }\end{array}$ & $\begin{array}{l}2,258 \text { patients undergoing } \\
\text { major intra-abdominal } \\
\text { cancer surgery }\end{array}$ & BMI & $\begin{array}{l}\text { Underweight: } \mathrm{BMI} \leq 18.5(\mathrm{n}=55) \\
\text { Normal weight: } \mathrm{BMI}=18.5-25.5(\mathrm{n}=819) \\
\text { Overweight: } \mathrm{BMI}=25.1-30.0(\mathrm{n}=811) \\
\text { Obese I: } \mathrm{BMI}=30.1-35(\mathrm{n}=357) \\
\text { Obese II: } \mathrm{BMI}=35.1-40(\mathrm{n}=137) \\
\text { Obese III: } \mathrm{BMI}=40(\mathrm{n}=79)\end{array}$ \\
\hline $\begin{array}{l}\text { Diaz-Montez, } \\
2007 \\
\text { (USA) [23] }\end{array}$ & $\begin{array}{l}\text { January } 1, \\
\text { 1994, to } \\
\text { June } 30,2004\end{array}$ & $\begin{array}{l}\text { Retro- } \\
\text { spective }\end{array}$ & $\begin{array}{l}95 \text { ovarian cancer } \\
\text { surgery patients }\end{array}$ & $\begin{array}{l}\text { BMI and serum } \\
\text { albumin }\end{array}$ & $\begin{array}{l}\text { BMI levels }<30, \geq 30 \text {, and unknown } \\
\text { Albumin levels }<3.5 \mathrm{~g} / \mathrm{dl} \text { (reference group) and } \geq 3.5 \mathrm{~g} / \mathrm{dl}\end{array}$ \\
\hline
\end{tabular}

\begin{tabular}{|c|c|c|c|c|c|}
\hline $\begin{array}{l}\text { Lohsiriwat, } \\
2007 \\
\text { (Thailand) [13] }\end{array}$ & $\begin{array}{l}\text { January } 2004 \\
\text { to December } \\
2005\end{array}$ & $\begin{array}{l}\text { Retro- } \\
\text { spective }\end{array}$ & $\begin{array}{l}84 \text { patients with adeno- } \\
\text { carcinoma of the } \\
\text { right-sided colon }\end{array}$ & Serum albumin & $\begin{array}{l}\text { Nonhypoalbuminemic: albumin } \geq 3.5 \mathrm{~g} / \mathrm{dl}(\mathrm{n}=36) \\
\text { Hypoalbuminemic: albumin }<3.5 \mathrm{~g} / \mathrm{dl}(\mathrm{n}=48)\end{array}$ \\
\hline $\begin{array}{l}\text { De Luis, } \\
2006 \\
\text { (Spain) [22] }\end{array}$ & $\begin{array}{l}\text { January } 1999 \\
\text { to December } \\
2003\end{array}$ & $\begin{array}{l}\text { Retro- } \\
\text { spective }\end{array}$ & $\begin{array}{l}1,088 \text { patients: leukemia } \\
\text { and lymphoma }(11.5 \%) \text {, } \\
\text { solid cancer }(37.4 \%)\end{array}$ & $\begin{array}{l}\text { BMI } \\
\text { Albumin } \\
\text { Mid-arm muscle } \\
\text { area } \\
\text { Mid-arm muscle } \\
\text { circumference } \\
\text { Weight loss }\end{array}$ & $\begin{array}{l}\text { Weight loss, mid-arm muscle circumference, and mid-arm } \\
\text { muscle area. BMI and albumin were used as continuous } \\
\text { variables. }\end{array}$ \\
\hline
\end{tabular}

\begin{tabular}{|c|c|c|c|c|c|}
\hline $\begin{array}{l}\text { Massad, } \\
1993 \\
\text { (USA) [25] }\end{array}$ & $\begin{array}{l}\text { January } 1 \text {, } \\
1990 \text {, to } \\
\text { December } \\
31,1990\end{array}$ & $\begin{array}{l}\text { Retro- } \\
\text { spective }\end{array}$ & $\begin{array}{l}155 \text { gynecologic oncology } \\
\text { patients } \\
\text { Primary site: ovarian }(n=54) \text {, } \\
\text { endometrial }(n=46) \text {, cervical } \\
(n=33) \text {, vulvar }(n=10), \\
\text { fallopian }(n=4) \text {, peritoneal } \\
(n=2)\end{array}$ & $\begin{array}{l}\text { BMI and serum } \\
\text { albumin }\end{array}$ & BMI and serum albumin levels were used as continuous variables. \\
\hline
\end{tabular}




\begin{tabular}{|c|c|c|}
\hline RR/HR (95\% CI) or LOS comparison & Conclusion & Variables adjusted for \\
\hline $\begin{array}{l}\text { Results for } \mathrm{n}=434 \text {, OR for prolonged LOS }>15 \text { days: } \\
\text { BMI: univariate:1.47 }(0.80-2.69), \mathrm{p}=0.21 \text {; multivariate NS } \\
\text { Albumin: univariate: } 2.77(1.71-4.47), \mathrm{p}<0.01 \text {; multivariate, } 2.4(1.5-4.0) \text {, } \\
\text { significant } \\
\text { SGA: univariate: for SGA B: }-1.31(0.79-2.18), \mathrm{p}=0.30 \text {; for SGA C: } \\
\text {-1.86 (1.20-2.86), } \mathrm{p}<0.01 \text {; multivariate: NS } \\
\text { Weight loss: univariate: } 1.88(1.29-2.76), \mathrm{p}<0.01 \text {; multivariate: } 1.6 \\
\text { (1.1-3.4), significant } \\
\text { Serum lymphocyte count: univariate: } 1.65(1.13-2.43), \mathrm{p}=0.01 \text {; multivariate: NS }\end{array}$ & $\begin{array}{l}\text { The methods adopted for assessment } \\
\text { of the nutritional status appeared to be } \\
\text { weak predictors of death, infection, } \\
\text { and hospital stay. Except for low serum } \\
\text { albumin, isolated use of these methods } \\
\text { adds little information in identifying } \\
\text { the effect of nutritional status on clini- } \\
\text { cally relevant outcomes. }\end{array}$ & $\begin{array}{l}\text { Age, gender, nonsurgical } \\
\text { admission, cancer, C-statistic }\end{array}$ \\
\hline $\begin{array}{l}\text { Univariate: the total hospital stay in days expressed as the median (interquartile } \\
\text { range) was } 6(4-8) \text { in the case of each group, i.e. }<20 \text { and } \geq 20, p=0.820 \text {; } \\
\text { multivariate: NS }\end{array}$ & $\begin{array}{l}\text { BMI was not found to be significantly } \\
\text { associated with LOS. }\end{array}$ & $\begin{array}{l}\text { Age, American Society of } \\
\text { Anesthesiologists (ASA) grade, } \\
\text { sex, type of surgery and lesion }\end{array}$ \\
\hline $\begin{array}{l}\text { BMI: median LOS }=8 \text { days in each group }(<30 \text { and } \geq 30), p=0.289 \\
\text { Albumin change: median LOS in days }=8 \text { and } 7 \text {, respectively, for }<70 \% \text { and } \\
\geq 70 \%, p=0.489\end{array}$ & $\begin{array}{l}\text { Postoperative complications were the } \\
\text { only variables predictive of prolonged } \\
\text { LOS after colorectal resection. }\end{array}$ & $\begin{array}{l}\text { Coronary artery disease, diabetes } \\
\text { mellitus, chronic heart failure, chronic } \\
\text { obstructive pulmonary disease }\end{array}$ \\
\hline $\begin{array}{l}\text { Median in days (range) }=15(11.5-17), 10.5(9.5-15), 12(10-15.5) \text {, and } 13.5 \\
(11-19.5) \text {, respectively, for groups A, B, C, and D, NS }\end{array}$ & $\begin{array}{l}\text { Preoperative weight loss and low BMI } \\
\text { did not significantly influence the com- } \\
\text { plication rate, perioperative mortality } \\
\text { rate, LOS, or short-term prognosis. }\end{array}$ & None \\
\hline $\begin{array}{l}\text { Mean LOS in days }=13.5,11.2,11.7,10.6,11.7 \text {, and } 10.3 \text {, respectively, for the } \\
\text { underweight, normal weight, overweight, obese I, obese II, and obese III catego- } \\
\text { ries, } p=0.95\end{array}$ & $\begin{array}{l}\text { The differences in LOS across BMI } \\
\text { classes were not statistically significant. }\end{array}$ & None \\
\hline $\begin{array}{l}\text { BMI levels: } \\
\text { Univariate: among patients admitted for }<48 \mathrm{~h}, 23 \text { and } 13 \% \text { of patients, respec- } \\
\text { tively, had } \mathrm{BMI}<30, \geq 30 \text {, and unknown, while among those admitted for } \geq 48 \mathrm{~h} \text {, } \\
42,9 \text {, and } 3 \text { patients, respectively, had } \mathrm{BMI}<30, \geq 30 \text {, and unknown, } \mathrm{p}=0.05 \text {. } \\
\text { Multivariate: NS } \\
\text { Albumin levels: } \\
\text { Univariate: mean (range) }=3.74(2.1-4.9) \text { and } 3.37(1.4-4.6) \text {, respectively, for } \\
\text { those admitted for }<48 \text { and } \geq 48 \mathrm{~h}, \mathrm{p}=0.03 \text {. } \\
\text { Multivariate: } 0.23(0.07-0.77), \mathrm{p}=0.02\end{array}$ & $\begin{array}{l}\text { Extensive fluid resuscitation during } \\
\text { surgery, poor nutritional status, and } \\
\text { age } \geq 63 \text { years are associated with a } \\
\text { prolonged postoperative } \\
\text { SICU stay. }\end{array}$ & $\begin{array}{l}\text { Race, stage, bowel resection, ventilator } \\
\text { dependence, pulmonary artery } \\
\text { catheter, Charlson comorbidity index, } \\
\text { American Society of Anesthesiologists } \\
\text { score, CA-125, alkaline phosphatase, } \\
\text { ascites, operation room time, } \\
\text { hematocrit, estimated blood loss, } \\
\text { tumor size }\end{array}$ \\
\hline $\begin{array}{l}\text { Univariate: mean } \pm \mathrm{SD}=6.8 \pm 2.6 \text { days and } 9.6 \pm 4.7 \text { days for nonhypoalbumin- } \\
\text { emic and hypoalbuminemic groups, respectively, } \mathrm{p}=0.001 . \text { Multivariate: NS }\end{array}$ & $\begin{array}{l}\text { Serum albumin was significantly prog- } \\
\text { nostic for a greater LOS upon univari- } \\
\text { ate analysis but not upon } \\
\text { multivariate analysis. }\end{array}$ & None \\
\hline $\begin{array}{l}\text { LOS was divided into } 4 \text { quartiles: Q1 (<15 days), Q2 (16-23 days), Q3 (24-35 } \\
\text { days), and Q4 ( }>35 \text { days) } \\
\text { All results are expressed as means } \pm \text { SD: } \\
\text { Weight loss in kg: } 4.4 \pm 8.3,4.4 \pm 10.6,3.8 \pm 10.4 \text {, and } 4.7 \pm 8.9 \text {, respectively, for } \\
\text { Q1, Q2, Q3, and Q4, NS } \\
\text { Mid-arm muscle circumference in cm: } 21.8 \pm 3.2,22.4 \pm 3.4,22.8 \pm 3.4 \text {, and } \\
22.5 \pm 3.3 \text {, respectively, for Q1, Q2, Q3, and Q4, NS } \\
\text { Mid-arm muscle area in } \mathrm{cm}^{2}: 26.1 \pm 4.5,26.7 \pm 4.2,26.9 \pm 4.4 \text {, and } 26.7 \pm 4.3 \text {, } \\
\text { respectively, for Q1, Q2, Q3, and Q4, NS } \\
\text { BMI: } 23.2 \pm 4.8,24.3 \pm 4.6,24.14 \pm 4.5 \text {, and } 24.1 \pm 4.7 \text {, respectively, for Q1, } \\
\text { Q2, Q3, and Q4, NS } \\
\text { Albumin in g/dl: } 2.8 \pm 0.7,2.9 \pm 0.8,2.6 \pm 0.7 \text {, and } 2.5 \pm 0.6 \text {, respectively, } \\
\text { for Q1, Q2, Q3, and Q4, p }<0.05 \text {. } \\
\text { Correlation between albumin and LOS: } \mathrm{r}=-0.2 ; \mathrm{p}<0.05\end{array}$ & $\begin{array}{l}\text { The serum albumin levels are a good } \\
\text { marker of LOS; a decrease in admis- } \\
\text { sion levels produces an increase in } \\
\text { LOS. }\end{array}$ & Age, sex \\
\hline $\begin{array}{l}\text { BMI: NS } \\
\text { Albumin: } p<0.001\end{array}$ & $\begin{array}{l}\text { Hemoglobin and serum albumin were } \\
\text { inversely correlated with LOS, while } \\
\text { BMI was not. Interventions that opti- } \\
\text { mize hemoglobin and albumin preop- } \\
\text { eratively may result in decreased LOS. }\end{array}$ & $\begin{array}{l}\text { Age, race, attending physician, funded } \\
\text { versus charity care, pre-operative } \\
\text { medications or medical conditions, } \\
\text { preoperative hemoglobin, vulvar or } \\
\text { fallopian tube primary, estimated } \\
\text { surgical blood loss, prior platinum- } \\
\text { based chemotherapy, prior } \\
\text { radiotherapy remote from surgery, } \\
\text { other primary sites }\end{array}$ \\
\hline
\end{tabular}


Table 3. Relationship between nutritional status (assessed using others measures) and LOS

\begin{tabular}{|c|c|c|c|c|}
\hline $\begin{array}{l}\text { First author, } \\
\text { year (study place) }\end{array}$ & $\begin{array}{l}\text { Data collection } \\
\text { period }\end{array}$ & Study design & Sample size & $\begin{array}{l}\text { Nutritional assessment } \\
\text { method }\end{array}$ \\
\hline $\begin{array}{l}\text { Guo, } 2010 \\
\text { (China) }[10]\end{array}$ & $\begin{array}{l}\text { January } 2004 \text { to } \\
\text { December } 2007\end{array}$ & Prospective & $\begin{array}{l}314 \text { gastric } \\
\text { carcinoma patients }\end{array}$ & NRS-2002 \\
\hline
\end{tabular}

\begin{tabular}{|c|c|c|c|}
\hline $\begin{array}{l}\text { Pressoir, } 2010 \\
\text { (France) [28] }\end{array}$ & $\begin{array}{l}\text { October } 2007 \text { to } \\
\text { January } 2008\end{array}$ & $\begin{array}{l}\text { Prospective, } \\
\text { observational } \\
\text { multicenter study }\end{array}$ & $\begin{array}{l}1,545 \text { hospitalized cancer patients. } \\
\text { Type: breast }(n=375) \text {, head and neck }(n=179) \text {, colorectal } \\
(n=156) \text {, hematological }(n=156) \text {, gynecological }(n=137) \text {, } \\
\text { upper digestive }(n=103) \text {, lung }(n=90) \text {, others }(n=349)\end{array}$ \\
\hline $\begin{array}{l}\text { Amaral, } 2008 \\
\text { (Portugal) [1] }\end{array}$ & $\begin{array}{l}\text { March } 2005 \text { to } \\
\text { June } 2005\end{array}$ & Prospective & $\begin{array}{l}130 \text { cancers patients. } \\
\text { Type: head and neck }(n=27) \text {, peritoneal and gastrointestinal } \\
(n=25) \text {, breast }(n=23) \text { genitourinary system }(n=17) \text { lymph } \\
\text { ganglia }(n=10) \text {, endocrine glands }(n=6) \text {, soft tissues }(n=5) \text {, } \\
\text { respiratory system and thoracic organs }(n=5) \text {, bones and } \\
\text { joints }(n=4) \text {, hematopoietic system and endothelial reticulum } \\
(n=2) \text {, eye and lachrymal gland }(n=1) \text {, others }(n=1)\end{array}$ \\
\hline
\end{tabular}

Recommendations of the French health authority using age, BMI, and weight loss

NRS-2002, MUST, and MST $(n=2)$, eye and lachrymal gland $(n=1)$, others $(n=1)$

\begin{tabular}{lll}
\hline $\begin{array}{l}\text { Santoso, 2000 } \\
\text { (Australia) [29] } 1996\end{array}$ & $\begin{array}{l}\text { Prospective, } \\
\text { consecutive case } \\
\text { series }\end{array}$ & $\begin{array}{l}67 \text { gynecologic oncology patients. } \\
\text { Primary tumor site: cervix }(\mathrm{n}=32), \text { uterus }(\mathrm{n}=16) \text { ovary } \\
(\mathrm{n}=11), \text { vulva }(\mathrm{n}=1)\end{array}$
\end{tabular}

\author{
Prognostic Nutritional \\ Index based on serum \\ albumin, transferrin, triceps \\ skinfold, and skin sensitivity \\ tests
}

nutritional status is the fact that it is often found to be within normal limits in individuals with severe anorexia nervosa, when even an untrained eye can detect malnutrition in this population.

BMI was not found to be a good indicator of LOS. The BMI reflects patients' weight and height, and then assumptions are made about body composition based on the BMI. It does not take into account a decline in oral intake or clinically significant weight changes with a corresponding loss of body cell mass, which may have occurred prior to hospitalization. Clinically significant weight loss has previously been found to be associated with morbidity and mortality. Moreover, individuals with BMIs $<18.5$ are not always malnourished or undernourished, whereas individuals with a normal BMI can be malnourished. It is also likely that there is a wide variation in body composition and nutritional status in the overweight and obese populations. Interestingly, in this review tools like the NRS and
MUST, which take into account weight loss and declines in intake in addition to the BMI, did correlate with LOS.

Like most other systematic reviews, this review also suffers from potential publication bias. In general, this bias exists when studies reporting positive associations are more likely to get published. It remains possible that some unpublished studies containing valuable data might have gone undetected. Since we restricted this systematic review to include studies published in English only, it is possible that language bias might have affected our conclusions. Despite these limitations, we believe that the extensive available literature reviewed here demonstrates a strong association between nutritional status and LOS in cancer.

We propose some new avenues for further research in this area. The role of timely nutritional assessment and intervention in oncology cannot be overemphasized. Despite this, there is no consensus on how to manage patients based on any nutritional metric reviewed. This re- 


\begin{tabular}{|c|c|c|c|}
\hline Groups being compared & $\mathrm{RR} / \mathrm{HR}$ (95\% CI) or LOS comparison & Conclusion & $\begin{array}{l}\text { Variables } \\
\text { adjusted for }\end{array}$ \\
\hline $\begin{array}{l}\text { Nutritional risk used as a categorized variable } \\
\text { Preoperative NRS-2002 }<3 \text { and preoperative } \\
\text { NRS-2002 } \geq 3 \\
\text { Nutritional risk used as a continuous variable }\end{array}$ & $\begin{array}{l}\text { Mean } \pm S D=13.60 \pm 7.24 \text { days and } \\
19.06 \pm 11.79 \text { days, respectively, for NRS- } 2002 \\
<3 \text { and NRS- } 2002 \geq 3, p=0.000 \\
r=0.177, p=0.002\end{array}$ & $\begin{array}{l}\text { Preoperative nutrition score } \\
\text { (NRS-2002) } \geq 3 \text { predicted more } \\
\text { postoperative complications and } \\
\text { longer LOS. }\end{array}$ & None \\
\hline $\begin{array}{l}\text { Malnutrition absent }(69.1 \%) \text { and present }(30.9 \%) \\
\text { Among those with malnutrition: moderate } \\
(18.6 \%) \text {, severe }(12.2 \%) \\
\text { Note: LOS was available only for } 879 \text { patients }\end{array}$ & $\begin{array}{l}\text { Median LOS in days }=19.3 \pm 19.4 \text { and } \\
13.3 \pm 19.4 \text {, respectively, for those without and } \\
\text { with malnutrition, } p<0.0001\end{array}$ & $\begin{array}{l}\text { In French comprehensive cancer } \\
\text { centers, } 1 \text { out of } 3 \text { cancer patients } \\
\text { are malnourished and this was } \\
\text { associated with a longer LOS. }\end{array}$ & None \\
\hline $\begin{array}{l}\text { Based on NRS-2002: NRS- } 2002<3 \text { (well } \\
\text { nourished) (reference group) and NRS- } 2002 \geq 3 \\
\text { (undernourished) } \\
\text { Based on MUST: MUST }<1 \text { (low risk of } \\
\text { malnutrition) (reference group) and MUST } \geq 1 \\
\text { (high risk of malnutrition) } \\
\text { Based on MST: MST }<2 \text { (low risk of } \\
\text { malnutrition) (reference group) and MST } \geq 2 \\
\text { (high risk of malnutrition) }\end{array}$ & $\begin{array}{l}\text { Univariate: mean LOS in days (mean } \pm \text { SD) }= \\
7.5 \pm 4.4 \text { and } 12.5 \pm 11.9, \text { respectively, for NRS- } \\
2002<3 \text { (well nourished) and NRS-2002 } \geq 3 \\
\text { (undernourished), } \mathrm{p}=0.016 . \text { OR for an LOS of } \\
\geq 7 \text { days } \\
\text { Multivariate: } \\
\text { NRS: } \\
\quad \text { Crude OR: } 2.13(0.89-5.17), \mathrm{NS} \\
\quad \text { Adjusted OR: } 2.47(1.05-5.80), \mathrm{p}=0.003 \\
\text { MUST: } \\
\quad \text { Crude OR: } 3.19(1.43-7.16), \mathrm{p}<0.001 \\
\quad \text { Adjusted OR: } 3.24(1.50-7.00), \mathrm{p}=0.038 \\
\quad \text { MST: Crude OR: } 2.16(0.75-6.42), \mathrm{NS} \\
\quad \text { Adjusted OR: } 2.31(0.84-6.36), \mathrm{NS}\end{array}$ & $\begin{array}{l}\text { MUST had the highest agreement } \\
\text { with NRS- } 2002 \text { in hospitalized } \\
\text { cancer patients and better } \\
\text { identified patients at risk for a } \\
\text { longer LOS. }\end{array}$ & Sex, age \\
\hline $\begin{array}{l}\text { Prognostic Nutritional Index used as a } \\
\text { categorized variable } \\
\quad<40 \text {, nourished }(\mathrm{n}=31) ; \geq 40 \text {, malnourished } \\
\quad(\mathrm{n}=36) \text {. } \\
\text { Prognostic Nutritional Index used as a } \\
\text { continuous variable }\end{array}$ & $\begin{array}{l}\text { Prognostic Nutritional Index used as a } \\
\text { categorized variable } \\
\text { LOS in days described as the median } \\
\text { (interquartile range) }=6(4-7) \text { and } 8(6- \\
\text { 15.5), respectively, for nourished and } \\
\text { malnourished groups, } \mathrm{p}=0.004 \text {. } \\
\text { Prognostic Nutritional Index used as a } \\
\text { continuous variable: } \mathrm{r}=0.32, \mathrm{p}=0.009\end{array}$ & $\begin{array}{l}\text { Malnutrition is common in } \\
\text { gynecologic oncology patients and } \\
\text { contributes to longer hospital } \\
\text { stays. }\end{array}$ & None \\
\hline
\end{tabular}

view provides a strong rationale for devising such standards of practice and testing their value in controlled clinical studies. This would apply for all clinical manifestations of malnutrition broadly, as well as specific situations where a causative relationship is apparent. Another useful research area to pursue would be the investigation of the relationship between nutritional assessment and intervention and LOS across different countries to gain a better understanding of how the nutritional assessment and intervention practices differ across several nations.

\section{Conclusions}

Based on this review, it appears that nutritional status measured using a validated tool such as SGA/PG-SGA is a better predictor of LOS in gastrointestinal cancers requiring surgery compared with nonsurgical gastrointestinal cancer patients. Since surgery is associated with morbidity like infections and wound complications, which can increase LOS, it may be prudent to provide nutrition support during the perioperative period in these individuals. It makes sense to implement the ASPEN guidelines for oncology patients, which include nutritional screening, assessment, and intervention as appropriate. Correcting malnutrition may decrease the LOS and perhaps even lowers the rate of hospital readmissions in this population.

\section{Funding} ica $^{\circledR}$.

This study was funded by Cancer Treatment Centers of Amer-

Ann Nutr Metab 2011;59:96-106 


\section{References}

-1 Amaral TF, Antunes A, Cabral S, Alves P, Kent-Smith L: An evaluation of three nutritional screening tools in a Portuguese oncology centre. J Hum Nutr Diet 2008;21:575583.

2 Paccagnella A, Morello M, Da Mosto MC, Baruffi C, Marcon ML, Gava A, Baggio V, Lamon S, Babare R, Rosti G, Giometto M, Boscolo-Rizzo P, Kiwanuka E, Tessarin M, Caregaro L, Marchiori C: Early nutritional intervention improves treatment tolerance and outcomes in head and neck cancer patients undergoing concurrent chemoradiotherapy. Support Care Cancer 2010;18:837845.

3 Kyle UG, Genton L, Pichard C: Hospital length of stay and nutritional status. Curr Opin Clin Nutr Metab Care 2005;8:397-402.

-4 Odelli C, Burgess D, Bateman L, Hughes A, Ackland S, Gillies J, Collins CE: Nutrition support improves patient outcomes, treatment tolerance and admission characteristics in oesophageal cancer. Clin Oncol (R Coll Radiol) 2005;17:639-645.

$\checkmark 5$ Bauer J, Capra S, Ferguson M: Use of the scored Patient-Generated Subjective Global Assessment (PG-SGA) as a nutrition assessment tool in patients with cancer. Eur J Clin Nutr 2002;56:779-785.

-6 Laky B, Janda M, Bauer J, Vavra C, Cleghorn G, Obermair A: Malnutrition among gynaecological cancer patients. Eur J Clin Nutr 2007;61:642-646.

-7 Ramos CM, Boleo-Tome C, Monteiro-Grillo I, Camilo M, Ravasco P: The diversity of nutritional status in cancer: new insights. Oncologist 2010;15:523-530.

$\checkmark 8$ Isenring E, Cross G, Kellett E, Koczwara B, Daniels L: Nutritional status and information needs of medical oncology patients receiving treatment at an Australian public hospital. Nutr Cancer 2010;62:220-228.

9 Wu BW, Yin T, Cao WX, Gu ZD, Wang XJ, Yan M, Liu BY: Clinical application of subjective global assessment in Chinese patients with gastrointestinal cancer. World J Gastroenterol 2009; 15:3542-3549.

-10 Guo W, Ou G, Li X, Huang J, Liu J, Wei H: Screening of the nutritional risk of patients with gastric carcinoma before operation by NRS 2002 and its relationship with postoperative results. J Gastroenterol Hepatol 2010; 25:800-803.

-11 Rodriguez L: Nutritional status: assessing and understanding its value in the critical care setting. Crit Care Nurs Clin North Am 2004;16:509-514.
12 Skipworth J, Foster J, Raptis D, Hughes F: The effect of preoperative weight loss and body mass index on postoperative outcome in patients with esophagogastric carcinoma. Dis Esophagus 2009;22:559-563.

13 Lohsiriwat V, Chinswangwatanakul V, Lohsiriwat S, Akaraviputh T, Boonnuch W, Methasade A, Lohsiriwat D: Hypoalbuminemia is a predictor of delayed postoperative bowel function and poor surgical outcomes in right-sided colon cancer patients. Asia Pac J Clin Nutr 2007;16:213-217.

14 Laky B, Janda M, Kondalsamy-Chennakesavan S, Cleghorn G, Obermair A: Pretreatment malnutrition and quality of life - association with prolonged length of hospital stay among patients with gynecological cancer: a cohort study. BMC Cancer 2010;10: 232.

15 Norman K, Pichard C, Lochs H, Pirlich M: Prognostic impact of disease-related malnutrition. Clin Nutr 2008;27:5-15.

16 Shirodkar M, Mohandas KM: Subjective global assessment: a simple and reliable screening tool for malnutrition among Indians. Indian J Gastroenterol 2005;24:246250.

17 Ulander K, Jeppsson B, Grahn G: Postoperative energy intake in patients after colorectal cancer surgery. Scand J Caring Sci 1998;12: 131-138.

18 Wakahara T, Shiraki M, Murase K, Fukushima H, Matsuura K, Fukao A, Kinoshita S, Kaifuku N, Arakawa N, Tamura T, Iwasa J, Murakami N, Deguchi T, Moriwaki H: Nutritional screening with Subjective Global Assessment predicts hospital stay in patients with digestive diseases. Nutrition 2007;23: 634-639.

19 Wu B, Yin TT, Cao W, Gu ZD, Wang X, Yan M, Liu B: Validation of the Chinese version of the Subjective Global Assessment scale of nutritional status in a sample of patients with gastrointestinal cancer. Int J Nurs Stud 2010; 47:323-331.

20 Horsley P, Bauer J, Gallagher B: Poor nutritional status prior to peripheral blood stem cell transplantation is associated with increased length of hospital stay. Bone Marrow Transplant 2005;35:1113-1116.

21 Beghetto MG, Luft VC, Mello ED, Polanczyk CA: Accuracy of nutritional assessment tools for predicting adverse hospital outcomes. Nutr Hosp 2009;24:56-62.

22 de Luis DA, Izaola O, Cuellar L, Terroba MC, Cabezas G, Rojo S, Aller R, Sagrado MG: Nutritional assessment: predictive variables at hospital admission related with length of stay. Ann Nutr Metab 2006;50:394-398.
23 Diaz-Montes TP, Zahurak ML, Bristow RE: Predictors of extended intensive care unit resource utilization following surgery for ovarian cancer. Gynecol Oncol 2007;107: 464-468.

24 Leung AM, Gibbons RL, Vu HN: Predictors of length of stay following colorectal resection for neoplasms in 183 Veterans Affairs patients. World J Surg 2009;33:2183-2188.

25 Massad LS, Vogler G, Herzog TJ, Mutch DG: Correlates of length of stay in gynecologic oncology patients undergoing inpatient surgery. Gynecol Oncol 1993;51:214-218.

26 Hendry PO, Hausel J, Nygren J, Lassen K, Dejong CH, Ljungqvist O, Fearon KC: Determinants of outcome after colorectal resection within an enhanced recovery programme. Br J Surg 2009;96:197-205.

$\checkmark 27$ Mullen JT, Davenport DL, Hutter MM, Hosokawa PW, Henderson WG, Khuri SF, Moorman DW: Impact of body mass index on perioperative outcomes in patients undergoing major intra-abdominal cancer surgery. Ann Surg Oncol 2008;15:2164-2172.

28 Pressoir M, Desne S, Berchery D, Rossignol G, Poiree B, Meslier M, Traversier S, Vittot M, Simon M, Gekiere JP, Meuric J, Serot F, Falewee MN, Rodrigues I, Senesse P, Vasson MP, Chelle F, Maget B, Antoun S, Bachmann P: Prevalence, risk factors and clinical implications of malnutrition in French Comprehensive Cancer Centres. Br J Cancer 2010; 102:966-971.

29 Santoso JT, Canada T, Latson B, Aaaadi K, Lucci JA 3rd, Coleman RL: Prognostic nutritional index in relation to hospital stay in women with gynecologic cancer. Obstet Gynecol 2000;95:844-846.

$>30$ Dixon MR, Haukoos JS, Udani SM, Naghi JJ, Arnell TD, Kumar RR, Stamos MJ: Carcinoembryonic antigen and albumin predict survival in patients with advanced colon and rectal cancer. Arch Surg 2003;138:962-966.

$>31$ Sun LC, Chu KS, Cheng SC, Lu CY, Kuo CH, Hsieh JS, Shih YL, Chang SJ, Wang JY: Preoperative serum carcinoembryonic antigen, albumin and age are supplementary to UICC staging systems in predicting survival for colorectal cancer patients undergoing surgical treatment. BMC Cancer 2009;9:288.

32 Lis CG, Grutsch JF, Vashi PG, Lammersfeld CA: Is serum albumin an independent predictor of survival in patients with breast cancer? JPEN J Parenter Enteral Nutr 2003;27: $10-15$. 